\title{
Analysis of the Impact of State Governance on the Stability of Islamic Bank Across 20 Countries
}

\author{
Maima Widya Adiputri \\ Departement of Management \\ Faculty of Economics and Business \\ Universitas Indonesia \\ Depok, Indonesia \\ namasaya.aima@gmail.com
}

\author{
Liyu Adhi Kasari Sulung \\ Departement of Management \\ Faculty of Economics and Business \\ Universitas Indonesia \\ Depok, Indonesia \\ liyu.adhi@ui.ac.id
}

\begin{abstract}
The purpose of this research is to examine the stability of Islamic banks across 20 countries that are influenced by the role of their governance. This study uses unbalanced panel data and fixed effect model to operate the data. From this study, the researcher found that supportive country governance and efficient contract enforcement induce Islamic banking stability. Those country governance variables which support the positive effect on Islamic bank stability are control of corruption, political stability, and regulatory quality
\end{abstract}

Keywords-Islamic bank, Country governance, bank stability, control of corruption, political stability, regulatory quality

\section{INTRODUCTION}

The Islamic banking industry has expanded broadly during the past three decades. The governance and institutions for Islamic banking have affected this growth. In 2004, the Financial Services Authority approved the first Islamic bank in Britain - the Islamic Bank of Britain. Through institutional support, the Islamic Bank of Britain opened its branch in the same year.

However, Islamic banking is not only developing in the country through steady governance and institutions. Amid conflict and government turmoil, Islamic banks still operate in the MENA region. In this circumstance, Islamic banks in MENA face higher risk than countries with stable governments. During the conflict, Egypt and Jordan succeeded in maintaining their macroeconomic stability but failed to improve their unemployment rate and economic growth. Belkhir, Grira, Hassan, and Soumare [1] found that Islamic banks are less affected than conventional banks by political risk.

Country governance indicators were initiated by Kaufmann, Kraay, and Mastruzzi [2]. They classified country governance into six dimensions: voice of accountability, control of corruption, political stability and absence of violence, government effectiveness, regulatory quality, and rule of law. A previous study on country governance by Curti and Mihov [3] found that average country governance is significantly related to bank fraud recovery. On an individual test, these dimensions positively affected bank fraud recovery, except for political stability and voice of accountability. Chan, Koh, Zainir, and Yong [4] argued that political stability and regulatory quality could improve bank efficiency in a highly concentrated market.
Furthermore, a country's legality plays a vital role in banking stability. La Porta, Lopez-de-Silanes, and Shleifer [5] argued that the legal system affects the policy framework and economic reform. Demirgüç-Kunt and Detragiache [6] found that deposit insurance stimulates moral hazards and increases the probability of a crisis occurring. Moreover, Demirgüç-Kunt and Detragiache [6] stated that governance quality contributes to bank regulation and control. Djankov, McLiesh, and Shleifer [7] and Porta [5] found that the legal system has an impact on creditor and investor protection. Legal characteristics from each country affect bank stability [8]. They also found that listing status has an impact on bank risk.

This study attempts to explore the effect of state governance, contract enforcement, and the legal system on Islamic bank stability. We employ five country governance concepts: control of corruption, political stability, government effectiveness, regulatory quality, and rule of law. We use a sample from Islamic banks in 20 countriesBahrain, Bangladesh, Brunei Darussalam, Egypt, Indonesia, Iran, Iraq, Jordan, Kuwait, Malaysia, Mauritania, Pakistan, Palestine, Qatar, Arab Saudi, Sudan, Syria, Turkey, United Arab Emirates, and the United Kingdom.

\section{LITERATURE REVIEW AND HYPOTHESIS DEVELOPMENT}

\section{A. Islamic Bank Stability}

Studies find that Islamic banks are steadier than conventional banks during crises. Hasan and Dridi [9], and Olson and Zoubi [10] argued that, during crises, Islamic banks are more profitable. However after crises, their performance is worse than conventional banks. Financial crises are not only induced by economic factors but also by governance. The government's policy mechanisms related to the implementation of banking policies have varied impacts on each bank and are affected by stakeholders' power in ownership structures [11].

During conflict and political turmoil, Islamic banks continue to grow. Belkhir et al. [1] found that Islamic banks are not affected by political risk. Islamic bank resilience against crises is found by Boukhatem and Moussa [12]. They argued that no evidence exists that crises have an impact on Islamic banks' soundness, although they affect the macroeconomy. 


\section{B. Country Governance and Bank Stability}

Country governance is an essential facet in Islamic bank development. A supportive government that implements regulations and policies will encourage Islamic bank growth. Boukhatem and Moussa [12] used two country governance indicators: the rule of law, which includes contract enforcement quality and regulatory quality-measurements of the government's ability to formulate and implement policies for regulation. They found that, during pre-crises, those indicators negatively impacted a country's financial growth. Meanwhile, Demirgüç-Kunt and Detragiache [6] stated that government quality plays a role in controlling and regulating banks.

\section{Enforcement and Bank Stability}

Country governance is an essential facet in Islamic bank development. A supportive government that implements regulations and policies will encourage Islamic bank growth. Boukhatem and Moussa [12] used two country governance indicators: the rule of law, which includes contract enforcement quality and regulatory quality-measurements of the government's ability to formulate and implement policies for regulation. They found that, during pre-crises, those indicators negatively impacted a country's financial growth. Meanwhile, Demirgüç-Kunt and Detragiache [6] stated that government quality plays a role in controlling and regulating banks.

\section{Legal System and Bank Stability}

Samet et al. (2018, p.287) found that banks that operate in a common law system tend to take higher risk. They also found that bank stability is affected by the diversity of each country's legal character. Common law gives very strong protection to investors, whereas civil law has the worst investor protection [13]. La Porta, Lopez-de-Silanes, and Shleifer [5] argued that the legal system has an impact on policy frameworks and economic reform. Djankov, McLiesh, and Shleifer [7] and Porta [14] stated that a country's legal system affects creditor and investor protection.

\section{RESEARCH METHOD}

\section{A. Data}

The data used for this research are collected from the following six resources:

1) Financial statement and listing status from the Bankscope database; data from the balance sheet and income statement are used to calculate financial ratios and market concentration;

2) Country governance indicators compiled by Kaufmann, Kraay, and Mastruzzi [2] from The Worldwide Governance Indicators, World Bank;

3) Contract enforcement from The Doing Business, World Bank;

4) Creditor rights index and legal system from Djankov, McLiesh, and Shleifer [7] and La Porta, Lopez-deSilanes, and Shleifer [5];

5) Measuring whether a country has deposit insurance is obtained from IADI sites; countries that still develop deposit insurance systems are counted as having no deposit insurance system; and,

6) To control macroeconomic factors, we used GDP and inflation from the World Bank Database.
We only use banks for which data are available for at least three years. The sample period is from 2011 to 2015. Therefore, the sample for this research consists of 108 Islamic banks from 20 countries. Table I provides definitions for the variables.

\section{B. Model}

To examine the result, we regress country governance, bank level, macroeconomic, and market level variables on bank stability (Z-scores). Based on the collected data, we apply a panel model regression as our approach. We estimate the regression model used by Samet, Boubakri, and Boubaker [8]:

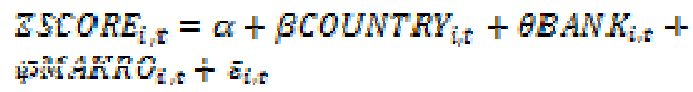

where $i$ and $t$ denote bank and time, respectively; $a$ is a constant; ZSCORE, is Ln Z-score; COMNTRY is an independent variable that includes contract enforcement and legal system; $B A N N_{i}$ represents bank-specific factors consisting of listing status, bank size, and asset growth. $\$ M A K R O_{i_{\star} t}$ includes GDP, inflation, Herfindahl-Hirsch index, and creditor rights index; $\vec{p}, \vec{\omega}$, and in are the extent to which the relative factors contribute to the change in the dependent variable and reflects the error term for bank $i$ and period $t$. We extend the previous model to test the relationship between country governance indicators and bank stability:

$$
\begin{aligned}
& Z \operatorname{SCORE}_{i, t}=a+\delta \operatorname{NST}_{i, t}+\beta C O U N T R Y_{i t}+\theta B A N K_{i, t}+ \\
& \text { MAKRO } O_{i, t}+\varepsilon_{i, t}
\end{aligned}
$$

where $\bar{N} \bar{N} \mathrm{H}_{i .5}$ represents control of corruption, government effectiveness, political stability, regulatory quality, and rule of law and $s$ is the extent to which relative factors contribute to changes in the dependent variable.

\section{RESUlt AND DisCUSSION}

\section{A. Descriptive Statistic Analysis}

Table II reports the summary statistics of the variables. Table II indicates that control of corruption from our sample is quite low, with an average value of -0.15 . The mean value of governance effectiveness is 0.01 , which shows that the government in the sample is not efficient in state administration activities. Political stability is low, with a mean value of -0.79 , indicating that the political situation in the country sample is unstable. The mean value of regulatory quality is -0.08 , which shows that governance quality in formulating and implementing is low. Public compliance with the legal system and contracts tends to be weak, as is indicated in the mean value of rule of law, at -0.1 . Banks that operate in a common law country represent $48 \%$ of the sample. The enforcement's mean value is 82.57, which indicates that banks are effectively enforcing contracts.We find that $53 \%$ of the banks in the sample are listed. On average, banks have $20 \%$ equity and $49 \%$ of its assets. Depins shows that $72 \%$ of the country sample already prevails with deposit insurance. The creditor rights index is 2.30 , indicating that, on average, protection for creditors is strong. 
TABLE I. VARIABLE DEFINITIONS

\begin{tabular}{|c|c|c|c|}
\hline Variable & Definition & Measurement & Data Source \\
\hline Z-Scores & Bank stability & 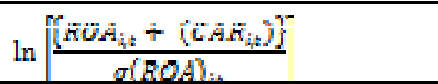 & Bankscope and authors' estimation \\
\hline \multicolumn{4}{|c|}{ Independent Variable } \\
\hline Cor & Corruption contro & $\begin{array}{l}\text { Ranges from }-2.50 \text { (weak) to } 2.50 \\
\text { (strong) }\end{array}$ & The index of national governance \\
\hline Gov & Government effectiveness & As above & As above \\
\hline $\mathrm{Pol}$ & Political stability & As above & As above \\
\hline Reg & Regulatory quality & As above & As above \\
\hline Rule & Rule of law & As above & As above \\
\hline Enforcement & Contract enforcement & $\begin{array}{l}\text { Ranges from } 0 \text { (weak enforcement) } \\
\text { to } 100 \text { (strong enforcement) }\end{array}$ & The Doing Business \\
\hline Common & Legal system & $1=$ common law, $0=$ others & $\begin{array}{l}\text { Djankov, McLiesh, and Shleifer [7] } \\
\text { and La Porta, Lopez-de-Silanes, and } \\
\text { Shleifer [5] }\end{array}$ \\
\hline \multicolumn{4}{|c|}{ Bank Level } \\
\hline CAR & Capitalization & 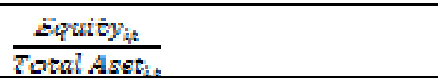 & Bankscope and authors' estimation \\
\hline Loans & Total loans & $\frac{\log _{h_{t}}}{\operatorname{sonh} A \operatorname{set}}$ & As above \\
\hline Public & Listing status & $1=$ public bank, $0=$ others & Bankscope \\
\hline Size & Bank size & Le'T Total Asset & As above \\
\hline Toobig & Bank share & $\begin{array}{l}1=\text { bank's share in a country excess } \\
10 \%, 0=\text { bank's share in a country } \\
\text { less than } 10 \%\end{array}$ & As above \\
\hline Growth & Bank growth & 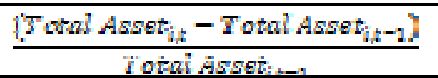 & As above \\
\hline \multicolumn{4}{|c|}{ Macroeconomic Factor } \\
\hline HHI & Market concentration & $g^{2}+g^{2}+\ldots+g^{2}$ & Bankscope and authors' estimation \\
\hline Depins & Deposit insurance & $\begin{array}{l}1=\text { a country has deposit insurance, } 0 \\
=\text { others }\end{array}$ & IADI \\
\hline GDP & GDP in US Dollar & $\ln (G D F)$ & The World Bank Database \\
\hline Inflation & Inflation rate & Inflation rate in percentage & The World Bank Database \\
\hline CRI & Creditor rights index & $\begin{array}{l}\text { This index ranges from } 0 \text { (weak } \\
\text { creditor rights protection) } \\
\text { (strong creditor protection) }\end{array}$ & $\begin{array}{l}\text { Djankov, McLiesh, and Shleifer [7] } \\
\text { and La Porta, Lopez-de-Silanes, and } \\
\text { Shleifer [5] }\end{array}$ \\
\hline
\end{tabular}

TABLE II. DESCRIPTIVE STATISTICS

\begin{tabular}{|l|l|l|l|l|l|l|}
\hline \multicolumn{1}{|c|}{ Variable } & \multicolumn{1}{c|}{ N } & \multicolumn{1}{c|}{ Mean } & S.D. & Median & Min & Max \\
\hline \multicolumn{1}{|c|}{ Depentent variable } & & & & & & \\
\hline Z-scores & 545 & 1.05 & 1.07 & 0.99 & -3.36 & 3.33 \\
\hline \multicolumn{1}{|c|}{ Independent variable } & & & & & & \\
\hline Control of corruption & 545 & -0.15 & 0.82 & -0.06 & -1.55 & 1.87 \\
\hline Governance & 545 & 0.01 & 0.89 & -0.02 & -1.63 & 1.74 \\
\hline Political stability & 545 & -0.79 & 1.07 & -0.93 & -2.94 & 1.25 \\
\hline Regulatory quality & 545 & -0.08 & 0.89 & 0.09 & -1.67 & 1.86 \\
\hline Rule of law & 545 & -0.10 & 0.77 & 0.26 & -1.52 & 1.89 \\
\hline Common & 540 & 0.48 & 0.50 & 0.00 & 0.00 & 1.00 \\
\hline Enforcement & 545 & 61.24 & 12.15 & 59.79 & 40.67 & 82.57 \\
\hline & & & & & & \\
\hline Public & 545 & 0.53 & 0.50 & 1.00 & 0.00 & 1.00 \\
\hline CAR & 545 & 0.20 & 0.25 & 0.12 & -1.11 & 0.99 \\
\hline Loans & 511 & 0.49 & 0.40 & 0.53 & -0.40 & 5.61 \\
\hline Size & 545 & 16.86 & 3.61 & 16.50 & -9.55 & 27.75 \\
\hline Toobig & 545 & 0.42 & 0.49 & 0.00 & 0.00 & 1.00 \\
\hline Growth & 542 & 0.18 & 0.27 & 0.15 & -0.57 & 2.65 \\
\hline HHI & 542 & 0.07 & 0.17 & 0.01 & 0.00 & 1.00 \\
\hline Depins & 545 & 0.72 & 0.45 & 1.00 & 0.00 & 1.00 \\
\hline GDP & 540 & 11.24 & 0.53 & 11.34 & -26.87 & 12.48 \\
\hline Inflation & 540 & 6.19 & 12.15 & 4.11 & 9.69 & 35.57 \\
\hline CRI & 357 & 2.30 & 0.72 & 2.00 & 1.00 & 4,00 \\
\hline & & & & & & \\
\hline
\end{tabular}


TABLE III. REGRESSION RESULTS FOR ALL MODELS

\begin{tabular}{|c|c|c|c|c|c|c|c|}
\hline Category Variable & & Model 1 & Model 2 & Model 3 & Model 4 & Model 5 & Model 6 \\
\hline \multicolumn{8}{|c|}{ Variable dependent $Z$-scores } \\
\hline & $\mathrm{C}$ & $\begin{array}{l}-30,1866 \\
(0,001)^{* *}\end{array}$ & $\begin{array}{l}-10,7282 \\
(0,071)^{* * *}\end{array}$ & $\begin{array}{l}-10,9012 \\
(0,068)^{* * *}\end{array}$ & $\begin{array}{l}-27,2611 \\
(0,002)^{* *}\end{array}$ & $\begin{array}{l}-10,2671 \\
(0,085)^{* * *}\end{array}$ & $\begin{array}{l}-9,7703 \\
(0,102)\end{array}$ \\
\hline \multicolumn{8}{|c|}{ Independent } \\
\hline \multirow{7}{*}{ country governance } & Cor & & $\begin{array}{l}0,3080 \\
(0,034)^{* *}\end{array}$ & & & & \\
\hline & Gov & & & $\begin{array}{l}0,1195 \\
(0,376)\end{array}$ & & & \\
\hline & Pol & & & & $\begin{array}{l}0,4216 \\
(0,003)^{* *}\end{array}$ & & \\
\hline & Reg & & & & & $\begin{array}{l}0,2538 \\
(0,046)^{* *}\end{array}$ & \\
\hline & Rule & & & & & & $\begin{array}{l}0,3590 \\
(0,0037)^{* *}\end{array}$ \\
\hline & Enforcement & $\begin{array}{l}0,3529 \\
(0,000)^{*}\end{array}$ & & & $\begin{array}{l}0,3078 \\
(0,000)^{*}\end{array}$ & & \\
\hline & Common & $\begin{array}{l}-1,0564 \\
(0,000)^{*}\end{array}$ & $\begin{array}{l}-1,7252 \\
(0,000)^{*}\end{array}$ & $\begin{array}{l}-1,7123 \\
(0,000)^{*}\end{array}$ & $\begin{array}{l}-1,2938 \\
(0,000)^{*}\end{array}$ & $\begin{array}{l}-1,6725 \\
(0,000)^{*}\end{array}$ & $\begin{array}{l}-1,6765 \\
(0,0000)^{*}\end{array}$ \\
\hline \multicolumn{8}{|c|}{ Control } \\
\hline \multirow{6}{*}{ Bank } & CAR & $\begin{array}{l}4,0106 \\
(0,000)^{*}\end{array}$ & $\begin{array}{l}4,0018 \\
(0,000)^{*}\end{array}$ & $\begin{array}{l}4,0140 \\
(0,000) *\end{array}$ & $\begin{array}{l}4,0027 \\
(0,000)^{*}\end{array}$ & $\begin{array}{l}3,9256 \\
(0,000)^{*}\end{array}$ & $\begin{array}{l}3,9735 \\
(0,000)^{*}\end{array}$ \\
\hline & Loans & $\begin{array}{l}0,2095 \\
(0,032)^{*}\end{array}$ & $\begin{array}{l}0,2160 \\
(0,026)^{* *}\end{array}$ & $\begin{array}{l}0,2107 \\
(0,031)^{* *}\end{array}$ & $\begin{array}{l}0,2208 \\
(0,022)^{* *}\end{array}$ & $\begin{array}{l}0,2070 \\
(0,033)^{* *}\end{array}$ & $\begin{array}{l}0,2004 \\
(0,039)^{* *}\end{array}$ \\
\hline & Public & $\begin{array}{l}10,0137 \\
(0,000)^{*}\end{array}$ & $\begin{array}{l}0,8068 \\
(0,009)^{* *}\end{array}$ & $\begin{array}{l}0,6336 \\
(0,061) * * *\end{array}$ & $\begin{array}{l}9,1295 \\
(0,000)^{*}\end{array}$ & $\begin{array}{l}0,7725 \\
(0,011)^{* *}\end{array}$ & $\begin{array}{l}0,7636 \\
(0,011)^{* *}\end{array}$ \\
\hline & Size & $\begin{array}{l}0,5952 \\
(0,000)^{*}\end{array}$ & $\begin{array}{l}0,5464 \\
(0,000)^{*}\end{array}$ & $\begin{array}{l}0,5854 \\
(0,000)^{*}\end{array}$ & $\begin{array}{l}0,5312 \\
(0,000)^{*}\end{array}$ & $\begin{array}{l}0,5617 \\
(0,000)^{*}\end{array}$ & $\begin{array}{l}0,5519 \\
(0,000)^{*}\end{array}$ \\
\hline & Toobig & $\begin{array}{l}-0,1979 \\
(0,104)\end{array}$ & $\begin{array}{l}-0,1737 \\
(0,153)\end{array}$ & $\begin{array}{l}-0,2050 \\
(0,093)^{*}\end{array}$ & $\begin{array}{l}-0,1713 \\
(0,156)\end{array}$ & $\begin{array}{l}-0,1821 \\
(0,133)\end{array}$ & $\begin{array}{l}-0,1879 \\
(0,121)\end{array}$ \\
\hline & Growth & $\begin{array}{l}-0,4941 \\
(0,000)^{*}\end{array}$ & $\begin{array}{l}-0,4529 \\
(0,001)^{* *}\end{array}$ & $\begin{array}{l}-0,4759 \\
(0,000)^{*}\end{array}$ & $\begin{array}{l}-0,4119 \\
(0,002)^{* *}\end{array}$ & $\begin{array}{l}-0,4565 \\
(0,001)^{* *}\end{array}$ & $\begin{array}{l}-0,4524 \\
(0,001)^{* *}\end{array}$ \\
\hline \multirow{5}{*}{$\begin{array}{l}\text { Macroeconomics and } \\
\text { market }\end{array}$} & HHI & $\begin{array}{l}0,6203 \\
(0,358)\end{array}$ & $\begin{array}{l}0,6359 \\
(0,343)\end{array}$ & $\begin{array}{l}0,6043 \\
(0,370)\end{array}$ & $\begin{array}{l}0,6358 \\
(0,340)\end{array}$ & $\begin{array}{l}0,5666 \\
(0,399)\end{array}$ & $\begin{array}{l}0,6522 \\
(0,331)\end{array}$ \\
\hline & DepIns & $\begin{array}{l}-0,0981 \\
(0,852)\end{array}$ & $\begin{array}{l}-2,0044 \\
(0,000)^{*}\end{array}$ & $\begin{array}{l}-2,2984 \\
(0,000)^{*}\end{array}$ & $\begin{array}{l}0,2225 \\
(0,674)\end{array}$ & $\begin{array}{l}-2,2074 \\
(0,000)^{*}\end{array}$ & $\begin{array}{l}-2,0701 \\
(0,000)^{*}\end{array}$ \\
\hline & GDP & $\begin{array}{l}0,4192 \\
(0,379)\end{array}$ & $\begin{array}{l}0,4599 \\
(0,332)\end{array}$ & $\begin{array}{l}0,4239 \\
(0,373)\end{array}$ & $\begin{array}{l}0,5290 \\
(0,262)\end{array}$ & $\begin{array}{l}0,4169 \\
(0,379)\end{array}$ & $\begin{array}{l}0,4049 \\
(0,392)\end{array}$ \\
\hline & Inflation & $\begin{array}{l}-0,0064 \\
(0,136)\end{array}$ & $\begin{array}{l}-0,0069 \\
(0,108)\end{array}$ & $\begin{array}{l}-0,0057 \\
(0,187)\end{array}$ & $\begin{array}{l}-0,0068 \\
(0,109)\end{array}$ & $\begin{array}{l}-0,0062 \\
(0,148)\end{array}$ & $\begin{array}{l}-0,0081 \\
(0,064)^{* * *}\end{array}$ \\
\hline & CRI & $\begin{array}{l}-4,3186 \\
(0,000)^{*}\end{array}$ & $\begin{array}{l}-3,9045 \\
(0,133)\end{array}$ & $\begin{array}{l}-0,5581 \\
(0,000)\end{array}$ & $\begin{array}{l}-4,2491 \\
(0,000)^{*}\end{array}$ & $\begin{array}{l}-0,6777 \\
(0,109)\end{array}$ & $\begin{array}{l}0,7971 \\
(0,068)^{* * *}\end{array}$ \\
\hline Observation & & 339 & 339 & 339 & 339 & 339 & 399 \\
\hline R-squared & & 0,1782 & 0,1889 & 0,1801 & 0,1986 & 0,1877 & 0,1886 \\
\hline \multirow[t]{2}{*}{ Prob $>F$} & & 0,0000 & 0,0000 & 0,0000 & 0,0000 & 0,0000 & 0,0000 \\
\hline & & FE & FE & FE & FE & FE & FE \\
\hline
\end{tabular}

These models are estimated using the fixed effect model. *, **, and *** denote significance at the $1 \%, 5 \%$, and $10 \%$ levels, respectively.

Table III indicates the regression results. This research divides the model into six models for each country governance indicator.

\section{1) Control of Corruption and Islamic Bank Stability}

The regression result from Table III indicate that control of corruption has a significant positive impact on Islamic bank stability, which is proved by the probability value of 0,034 that is significant at the $5 \%$ level. This finding is supported by Houston et al. [15], who also found that control of corruption has a positive influence on bank stability. Chen et al. [16] also argued that a country with more severe corruption results in banks taking greater risk.

These findings are in line with Toader et al. [17] which states that controlling corruption can improve the quality of bank credit and accelerate credit growth. This can be done with the support of designing the right legal policies and systems. Therefore, the worse the level of corruption in a country, the stability of the bank will decrease. Houston et al. [15] in his research revealed that control of corruption significantly had a positive influence on bank stability.

2) Government Effectiveness and Islamic Bank Stability

The regression results from Table III indicate that government effectiveness has no substantial impact on the stability of Islamic bank. This finding is in line with Houston et al. [15], who found no impact of government effectiveness on bank stability.

\section{3) Political Stability and Islamic Bank Stability}

The regression results from Table III indicate that political stability positively influence the Islamic bank stability. The probability value of 0.003 is significant at the 
5\% level. Belkhir et al. [1] also found that Islamic banks are more protected from political risk than conventional banks. This finding is also supported by Ghosh [18], who found that, during the Arab spring (conflicted and political turmoil in MENA region), Islamic banks take higher risk.

\section{4) Regulatory Quality and Islamic Bank Stability}

The regression results from Table III indicate that regulatory quality has a significant positive influence on Islamic bank stability, and the probability value of 0.046 is significant at the 5\% level. This result can be interpreted as better regulatory quality increasing bank stability, which is also supported by Houston et al. [15].

The government has an important role in the stability of the bank with the formulated policy framework and oversight of its implementation [19-21]. A good policy and implementation framework can enhance bank credibility. Thus, the trust of customers and investors towards banks will increase. Furthermore, the design of appropriate regulations also improves the banking system better and has an impact on reducing risk [19]. Fratzscher, Johann, \& Lambert [22] also support this finding by stating that higher capital buffers can improve bank stability. This happens because higher capital and strict regulations on the basis of equity calculations provide incentives for better risk management.

\section{5) Rule of Law and Islamic Bank Stability}

The regression results from Table III indicate that political stability in a nation positively influence the stability of Islamic bank, and the probability value of 0.037 is significant at the $5 \%$ level.

\section{6) Contract Enforcement and Islamic Bank Stability}

The regression results from Table III indicate that contract enforcement has a significant positive influence on Islamic bank stability, and the probability value of 0.000 in both models is significant at the 5\% level. This finding is supported by Levine [23], who found that a country with higher compliance and adherence to contract enforcement will increase bank stability.

\section{7) Legal System and Islamic Bank Stability}

The regression results from Table III indicate that common law has a significant negative influence on Islamic bank stability, and the probability value of 0.000 on all models is significant at the $5 \%$ level. This finding is in line with Samet et al. [8], who found that banks that operate in a common law system tend to take higher risks.

TABLE IV. SENSITIVITY ANALYSIS REGRESSION RESULt

\begin{tabular}{|l|c|c|c|c|}
\hline & Prediction & Sign & coefficient & prob \\
\hline Capital Expenditures & + & - & -0.049 & $0.017^{*}$ \\
\hline Goods and Services Expenditures & + & + & 0.031 & $0.056^{*}$ \\
\hline Total Asset & + & + & 4.000 & 0.167 \\
\hline Budget Total & + & - & -6666 & $0.017^{* * *}$ \\
\hline Level of Dependency & - & - & -0.004 & $0.037^{* * *}$ \\
\hline Local Original Revenue & + & + & 0.004 & 0.114 \\
\hline Cap Exp *control ineffectiveness & + & - & -0.001 & 0.259 \\
\hline Cap Exp*control weakness case & + & + & 0.000 & $0.007^{* * *}$ \\
\hline G\&S Exp* control ineffectiveness & + & + & 0.000 & 0.868 \\
\hline G\&S Exp* control weakness case & + & - & -0.000 & $0.009^{* * *}$ \\
\hline
\end{tabular}

\section{CONCLUSION AND IMPLICATION}

The purpose of this research is to prove the impact of country governance, contract enforcement, and the legal system, on Islamic bank stability during 2011-2015.

We found that control of corruption, political stability, regulatory quality, and rule of law have significant positive effects on bank stability while contract enforcement negatively affects Islamic bank stability. We found that the Islamic bank in a country with a common law takes more risk.

The government has an important role in the stability of the bank with the formulated policy framework and oversight of its implementation [19-21]. A good policy and implementation framework can enhance bank credibility.
Thus, the trust of customers and investors towards banks will increase. Furthermore, the design of appropriate regulations also improves the banking system better and has an impact on reducing risk

Future research may consider using these indicators by extending the scope of the observation that includes financial crises periods or government instability period in order to analyze the holistic view of the governance and macroeconomic impact on bank stability in every period.

\section{ACKNOWLEDGMENT}

We acknowledge this research was funded by the Directorate of Research and Community Engagement, Universitas 


\section{REFERENCES}

[1] M. Belkhir, J. Grira, M.K. Hassan, and I. Soumaré, "Islamic banks and political risk: International evidence," Quarterly Review of Economics and Finance, pp. 1-17, 2018. https://doi.org/10.1016/ j.qref.2018.04.006

[2] D. Kaufmann, A. Kraay, and M. Mastruzzi, "Governance Matters VI: Aggregate and Individual Governance Indicators for 1996-2006. World Bank Policy Research Paper No. 4280," 2007. https://doi.org/http://www-wds.worldbank.org/servlet/WDSContent Server/WDSP/IB/2006/09/15/000112742 20060915092802/Rendere d/PDF/wps4012.pdf

[3] F. Curti, and A. Mihov, "Fraud recovery and the quality of country governance," Journal of Banking and Finance, vol. 87, pp. 446-461, 2018. https://doi.org/10.1016/j.jbankfin.2017.11.009

[4] S.-G. Chan, E.H.Y. Koh, F. Zainir, \& C.-C. Yong, "Market structure, institutional framework and bank efficiency in ASEAN 5", Journal of Economics and Business, vol. 82, pp. 84-112, 2015.

[5] R. La Porta, F. Lopez-de-Silanes, and A. Shleifer, "The economic consequences of legal origins," Journal of Economic Literature, 46(2), pp. 285-332, 2008. https://doi.org/10.1257/jel.46.2.285

[6] A. Demirgüç-Kunt, and E. Detragiache, "Does deposit insurance increase banking system stability? An emperical investigation," Journal of Monetary Economics, vol. 49(7), pp. 1373-1406, 2002. https://doi.org/10.1016/S0304-3932(02)00171-X

[7] S. Djankov, C. McLiesh, and A. Shleifer, "Private credit in 129 countries," Journal of Financial Economics, vol. 84(2), pp. 299-329, 2007. https://doi.org/10.1016/j.jfineco.2006.03.004

[8] A. Samet, N. Boubakri, and S. Boubaker, "Does public-private status affect bank risk taking? Worldwide evidence," Journal of International Financial Markets, Institutions and Money, vol 53, 287-306, 2018. https://doi.org/10.1016/j.intfin.2017.12.007

[9] M. Hasan and J. Dridi, "The Effects of the Global Crisis on Islamic and Conventional Banks: A Comparative Study," IMF Working Paper vol. 02, 2010. https://doi.org/10.1142/S1793993311000270

[10] D. Olson and T. Zoubi, "Convergence in bank performance for commercial and Islamic banks during and after the Global Financial Crisis," Quarterly Review of Economics and Finance, vol. 65, 71-87, 2017. https://doi.org/10.1016/j.qref.2016.06.013

[11] L. Laeven and R. Levine, "Bank governance, regulation and risk taking," Journal of Financial Economics, vol. 93(2), pp. 259-275, 2009. https://doi.org/10.1016/j.jfineco.2008.09.003

[12] J. Boukhatem and F. Ben-Moussa, "The effect of Islamic banks on GDP growth: Some evidence from selected MENA countries," Borsa
Istanbul Review, vol 18(3), pp. 231-247, 2018. https://doi.org/ 10.1016/j.bir.2017.11.004

[13] R. La Porta, F. Lopez-de-Silanes, A. Shleifer, and R.W. Vishny, "Legal determinants of external finance," vol. 52(3), pp. 1131-1150,

1997. https://doi.org/10.1111/j.1540-6261.1997.tb02727.x

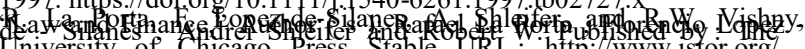
University of Chicago Press Stable URL: http://Www.jstor.org/ stable/10.1086/250042 Law and Finance Rafael La Porta, Floren, vol. 106(6), pp. 1113-1155, 1998.

[15] J.F. Houston, C. Lin, P. Lin, and Y. Ma, "Creditor rights, information sharing, and bank risk taking," Journal of Financial Economics, vol. 96(3), 485-512, 2010. https://doi.org/10.1016/j.jfineco.2010.02.008

[16] M. Chen, B.N. Jeon, R. Wang, and J. Wu, "Corruption and bank risktaking: Evidence from emerging economies," Emerging Markets Review, 24, pp. 122-148, 2015. https://doi.org/10.1016/j.ememar.2015.05.009

[17] T. Toader, M. Onofrei, A-I. Popescu, and A. Andries, "Corruption, and banking stability: Evidence from emerging economies," Emerging Markets Finance and Trade, vol. 54(3), pp. 591-617, 2018. https://doi.org/10.1080/1540496X.2017.1411257

[18] S. Ghosh, "Political transition and bank performance: How important was the Arab Spring?," Journal of Comparative Economics, vol. 44(2), pp. 372-382, 2016. https://doi.org/10.1016/j.jce.2015.02.001

[19] N. Alam, S.S. Zainuddin, and S.A.R. Rizvi, "Ramifications of varying banking regulations on performance of Islamic Banks," Borsa Istambul Review, vol. 19(1), pp. 49e64, 2018.

[20] T. Bermpei, and A. Kalyvas, and T.C. Nguyen, "Does institutional quality condition the effect of bank regulations and supervision on bank stability? Evidence from emerging and developing economies," International Review of Financial Analysis. ISSN 1057-5219 https://doi.org/10.1016/j.irfa.2018.06.002

[21] J. Klompa and J. de Haan, "Bank regulation and financial fragility in developing countries: Does bank structure matter?" Review of Development Finance, vol. 5(2), pp. 82-90, 2015

[22] M. Fratzscher, P.J. König, and C. Lambert, "Credit provision and banking stability after the Great Financial Crisis: The role of bank regulation and the quality of governance," Journal of International Money and Finance, vol. 66(C), p. 113-135, 2016

[23] R. Levine, "Law, finance, and economic growth," Journal of Financial Intermediation, vol .8 (1-2), pp. 8-35, 1999. 